13. Загальна теорія права : підручник / за заг. ред. М. І. Козюбри. Київ : Ваіте, 2015. 392 с.

14. Бряник Н. В. Динамика правопонимания в античности: от философии права Древней Греции к юриспруденции Древнего Рима. Науч. ежегодник Ин-та философии и права Урал. отд-ния Рос. акад. наук, 2018. Т. 18. Вып. 1. С. 7-23.

DOI https://doi.org/10.30525/978-9934-26-148-0-2

\title{
АКТУАЛЬНІ ПИТАННЯ РЕФОРМУВАННЯ ЮРИДИЧНОЇ ОСВІТИ В УКРАЇНІ
}

\author{
Гуменюк T. I. \\ доктор історичних наук, професор, професор кафедри права \\ ЗВО Університет Короля Данила \\ м. Івано-Франківськ, Украӥна
}

Актуальними постали проблеми перебудови існуючої системи підготовки юристів, озброєних сучасними знаннями, культурою, високим рівнем громадянської та соціальної свідомості. Основним завданням правника є утвердження всією своєю діяльністю верховенства, права перш за все через захист прав і свобод людини. Саме виходячи із таких завдань концепції, сформульована і мета юридичної освіти - це формування компетентностей, необхідних для розуміння природи і функцій права, змісту теоретичних засад, доктрин, принципів і основних юридичних інституцій, застосування права, а також меж юридичного регулювання суспільних відносин. Здобувачі юридичної освіти повинні бути готові до захисту прав людини та основоположних свобод, утвердження верховенства права, будучи відданими принципам людської та професійної гідності, справедливості, рівності, неупередженості, незалежності, співпереживання та дотримання високих.... Проблема, яка потребує розв'язання, $є$ невідповідність змісту юридичної освіти і якості підготовки в правничих школах вимогам ринку праці та тим викликам, що стоять перед сучасним демократичним суспільством, глобальним тенденціям розвитку і завданням професійної діяльності правника в різних сферах [1].

Вищі юридичні школи в різних європейських країнах мають певні спільні риси, обумовлені низкою чинників. Головною спільною рисою $\epsilon$ практичне спрямування навчального процесу та чітко означена професійна орієнтація юридичної освіти. Такий підхід обумовлюють 10 
ринок юридичних послуг і доступ до правничої професії. Саме ринок правничої професії найбільше впливає на формування навчальних планів. Перш за все, саме вища юридична школа повинна слідкувати за формуванням нових юридичних інститутів та механізмів, законотворчими процесами, а також за тенденціями розвитку національної правової доктрини [2]. Ефективність юридичної освіти та їі високий рівень залежать від низки факторів, серед яких важливе місце посідають використання результатів сучасних наукових досліджень при підготовці правників, застосування цифрових ресурсів, що дає змогу вирішити комплекс завдань: доступ студентів до результатів наукових досліджень, оприлюднених в електронній формі, електронних навчальних посібників/підручників і навчально-методичної літератури, участь у наукових i науково-практичних конференціях та інших наукових заходах, а також юридичних клініках, що застосовують дистанційне надання консультацій/правової допомоги. Реалізації ефективної освітньої політики сприятиме збалансованість традиційної освіти в галузі юриспруденції 3 використанням юридичного електронного навчання. Сучасна юридична освіта має грунтуватися, як це й традиційно передбачається, на досягненнях правової науки в поєднанні з навичками юридичної практики, а в сучасних умовах - із широким використанням надбань цифровізації, які дають змогу використати потенціал і юридичної освіти, і юридичної науки [3].

Диверсифікація й поява нових видів юридичної діяльності, розширення сфер правового регулювання мають спонукати до: розробки i формування на рівні освітніх політик компетентністної моделі правника, яка повинна сприяти подоланню істотного розриву між юридичною освітою і юридичною практикою; орієнтації на принцип змагальності, критичне мислення; впровадження інноваційних технологій навчання, інтерактивних методів викладання, а головне, нових дидактичних принципів навчання (спрямованість освітньої діяльності на результати навчання, їх систематичний моніторинг i самооцінку; академічну свободу учасників освітнього процесу; використання трансфертно-накопичувальної системи кредитів; принципу партнерства тощо). Означені напрямки сприятимуть створенню інноваційного освітнього середовища, забезпеченню конкурентоспроможності випускників на ринку праці та подальшій інтеграції юридичних вишів у європейський простір вищої освіти [4].

В умовах імплементації положень Болонського процесу щодо компетентнісного підходу принципового значення набувають: впровадження інноваційних освітніх програм, які мають відбивати запити ринку праці, модель сучасного правника, а по суті, глибокі 
виклики українського суспільства в цілому через інтерпретацію його конституційних цінностей, засад правової держави, гарантій прав людини і громадянина й верховенство права. 3 огляду на це освітні програми як інструмент управління освітньою політикою та проєктування освітньої діяльності мають ураховувати й охоплювати: затребуваність освітньої програми з точки зору різних стейкхолдерів державного i приватного сектору; стратегію навчання й оцінку досягнення запланованих результатів навчання; систему гарантій i оцінку якості освітньої програми; академічну мобільність, інтернаціональну компоненту, конкурентоспроможність випускників i модель їх професійної кар'єри. Формування стратегії освітньої діяльності правничих вишів і забезпечення академічної автономії через нову методологію й інтерпретацію змісту освітніх програм, сформульованих у термінах компетентностей, які імпліцитно відбивають структуру моделі сучасного правника через дескриптори компетентностей, зокрема, через: знання права, правничі професійні навички, знання про право та професійні цінності як соціальні орієнтири інтеріоризації у професійну діяльність правника у суспільстві. При цьому вкрай важливим при проєктуванні освітніх програм $є$ запровадження доктринального підходу до досягнення i вивчення права, міжнародного права, правової дійсності, правової системи, прикладних аспектів правореалізації, які можна інтерпретувати у аспекті загальних сучасної доктрини юридичної науки. Викладання доктрини, а не законодавства дозволить у дидактичному плані виокремити проблеми епістемології i методології правових досліджень, когнітивних i соціокультурних детермінант розвитку правових доктрин i теорій, правової аксіології, правової догматики, правової герменевтики, правозастосування, нормотворення, правової техніки, а також юридичної деонтології. Це дасть змогу вибудувати сучасну архітектектоніку, визначити зміст освітніх програм і перейти від жорсткого нормування змісту освіти до рамкової регламентації структури освітніх програм, що забезпечить розширення меж академічної автономії [5]. 3 урахуванням прийнятого рішення положення проєкту Концепції

потребують корегування задля найбільш точного та всеохоплюючого нормативного закріплення переліку професій, що передбачають правничу підготовку, адже до переліку визначених проєктом Концепції правничих спеціальностей не увійшли робота на посадах керівників та співробітників юридичних служб недержавного сектору економіки, а також помічників адвокатів, нотаріусів. У списку юридичних професій відсутні науковці-правники, детективи Національного антикорупційного бюро розслідувань, окремі категорії посад керівного та службо- 
вого складу Державного бюро розслідувань. Цілком очевидно, що визначений проєктом Концепції перелік правничих спеціальностей $\epsilon$ неповним та потребує доповнення 3 урахуванням змін сучасного законодавства [6, с. 65-66].

Основою побудови Загальної частини Основ законодавства України про освіту і науку повинні стати Закон України «Про освіту» [7]. та Закон України «Про наукову та науково-технічну діяльність» [8]. Основу реформування сучасної правничої освіти в Україні ключову роль відіграють наступні аспекти: 1) нормативно-правовий аспект, який передбачає формування цілісного Стандарту у сфері підготовки правників, включаючи визначення у ньому не лише вузькопрофесійних, а й загальних компетентностей, які базуються на загальнолюдських цінностях, європейських та міжнародних стандартах у сфері відношення до правового статусу особи; 2) організаційно-управлінський аспект, який має на меті модернізацію управління у сфері підготовки правників, а також сутності та змісту самоврядних засад, на базі яких здійснюють науково-педагогічну діяльність вищі навчальні заклади, які забезпечують підготовку правників. При цьому, провідна роль у цій сфері повинна належати науковій складовій та науковим школам, сформованим на базі вказаних закладів.

\section{Література:}

1. Інформація про слухання в Комітеті Верховної Ради України з питань освіти, науки та інновацій на тему: «Реформування вищої юридичної освіти в Україні: проблеми і перспективи» від 11 листопада 2020 року. URL: http://kno.rada.gov.ua/news/Robota_Kom/Parl_Kom_ slukh/Kom_slukh/IX_skl/75571.html

2. Калашник О.М. Проблеми інтеграції юридичної науки і освіти. Сучасна юридична освіта: досвід минулого - погляд у майбутнє. Матеріали Міжнародної науково-практичної конференції (м. Одеса, 21 жовтня 2016 року). Одеса, 2016. С. 90.

3. Вінник О., Шаповалова О., Попович Т. Юридична наука, юридична освіта й цифровізація: окремі аспекти взаємодії. Господарське право і проиес. 2020/3. С. 87.

4. Вища юридична освіта в XXI столітті: виклики й перспективи розвитку. URL: https://yurincom.com/legal_news/rezoliutsiiavseukrainskoikonferentsii-vyshcha-iurydychna-osvita-v-xxi-stolitti-vyklyky-jperspektyvy-rozvytku-04-hrudnia-2020-r/

5. Вища юридична освіта в XXI столітті: виклики й перспективи розвитку. URL: https://yurincom.com/legal_news/rezoliutsiiavseukrainskoi- 
konferentsii-vyshcha-iurydychna-osvita-v-xxi-stolitti-vyklyky-j-perspektyvy rozvytku-04-hrudnia-2020-r/

6. Білічак О.А. Реформа юридичної освіти в Україні: проблеми і виклики. Освітня аналітика України. 2019. № 3(7). С. 57-68.

7. Про освіту: Закон України від 05.09.2017. URL: https://zakon.rada.gov.ua/laws/show/2145-19\#Text.

8. Про наукову і науково-технічну діяльність: Закон України від 26.11.2015. URL: https://zakon.rada.gov.ua/laws/show/848-19\#Text.

DOI https://doi.org/10.30525/978-9934-26-148-0-3

\title{
РЕФОРМУВАННЯ ЮРИДИЧНОЇ ОСВІТИ В УКРАЇНІ: ТЕОРЕТИКО-ПРАВОВИЙ АНАЛІЗ
}

\author{
Друга А. А. \\ аспірантка кафедри державно-правових дисииплін \\ Міжнародного гуманітарного університету \\ м. Одеса, Україна
}

Останнім часом здійснено низку кроків із змістовної модернізації системи освіти в Україні, котрі спрямовані на підвищення якості української освіти, з інтеграцією останньої в європейський науковоосвітній простір. Переорієнтація на європейські стандарти якості освіти дали потужний імпульс реформам, що мають на меті приведення діяльності вищих навчальних закладів до найкращих світових практик. Особливе місце в цьому процесі займає реформування юридичної освіти, адже як слушно зазначає С. Ківалов: «модернізація вищої юридичної освіти в Україні вимагає подолання низки проблем, серед яких найбільш актуальними $є$ : невідповідність структури підготовки спеціалістів реальним потребам суспільства, зниження якості освіти, відірваність від прикладних наукових досліджень в галузі права, повільні темпи інтеграції в європейський і світовий інтелектуальний простір» [2, с. 4].

Сучасним проблемам реформування юридичної освіти приділялась увага в працях багатьох вітчизняних науковців, зокрема, В. Андрейцева, О. Білічака, К. Воронової, О. Діденко, В. Кузнєцова, К. Павлюка, О. Петришина, В. Тація, О. Ткачука, О. Чумака та ін. Проте, аналіз джерельної бази та сучасних тенденцій реформування юридичної освіти в Україні вказує на недостатній науковий рівень розробленості даної тематики, що обумовлює актуальність даного дослідження. 